\section{Journal Homepage: $-\underline{w w w . j o u r n a l i j a r . c o m}$ INTERNATIONAL JOURNAL OF ADVANCED RESEARCH (IJAR)}

Article DOI: $10.21474 / \mathrm{IJAR} 01 / 8322$

DOI URL: http://dx.doi.org/10.21474/IJAR01/8322

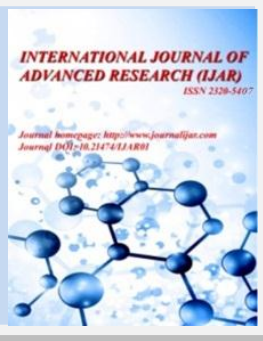

Abstract Page

\title{
EVALUATION OF DEXMEDETOMIDINE AS AN ADJUVANT TO ROPIVACAINE IN SUPRA- CLAVICULAR BLOCK FOR PATIENTS UNDERGOING UPPER LIMB PLASTIC SURGICAL PROCEDURES.
}

\author{
Summaira Jan ${ }^{1}$, Tawheed Ahmad ${ }^{2}$, Saima Rashid ${ }^{3}$ and Shabir Ahmad Langoo ${ }^{4}$. \\ 1. Registrar Anesthesia, Government Dental College Srinagar, India. \\ 2. Assistant Professor Plastic Surgery, KAAUH, Princess Nourah University, SA. \\ 3. Demonstrator Anatomy, Government Medical College Srinagar, India. \\ 4. Consultant Anesthesia, District Hospital Baramulla, India.
}

\section{Manuscript Info}

\section{Manuscript History}

Received: 04 November 2018

Final Accepted: 06 December 2018

Published: January 2019

Key words:-

Supra-clavicular block, Ropivacaine,

Dexmedetomidine, upper limb plastic surgeries.

\begin{abstract}
Background:Different adjuvants are used with local anesthetics to improve quality of peripheral nerve blocks. The aim of our study was to evaluate the effect of addition of dexmedetomidine with ropivacaine in supraclavicular brachial plexus block with respect to onset of sensory and motor blockade and duration of blockade and analgesia.

Patients and Methods: Sixty patients of ASA grade I and II, aged 1855 years of either sex scheduled for upper limb plastic surgical procedures under supraclavicular brachial plexus block were randomly divided into two equal groups. Patients in control group $\mathrm{R}(\mathrm{n}=30)$ received $29 \mathrm{ml}$ of $0.5 \%$ ropivacaine with $1 \mathrm{ml}$ normal saline (control) and in study group $\mathrm{RD}(\mathrm{n}=30)$ received $29 \mathrm{ml}$ of $0.5 \%$ ropivacaine with $1 \mathrm{ml}(50 \mu \mathrm{g})$ dexmedetomidine. The onset and duration of sensory and motor block, duration of analgesia were analyzed in both the groups

Results:The mean time of onset of sensory blockade were $5.1 \pm 0.91$ min and $3.2 \pm 0.82$ min respectively in group $\mathrm{R}$ and RD. Whereas time of onset of motor blockade were $11.21 \pm 1.81 \mathrm{~min}$ and $6.45 \pm 0.92 \mathrm{~min}$ respectively in group $\mathrm{R}$ and $\mathrm{RD}$. The durations of sensory and motor block were $455.31 \pm 19.31$ and $365 \pm 18.41$ min respectively in group $\mathrm{R}$, whereas they were $693 \pm 11.01$ and $656 \pm 18.26$ min respectively in group RD. The duration of analgesia was $481.31 \pm 16.01 \mathrm{~min}$ in group $\mathrm{R}$ compared to $718.32 \pm 11.25 \mathrm{~min}$ in group $\mathrm{RD}$ ( $\mathrm{p}<0.001)$. Statistically significant difference was found between the two groups with respect to their onset and duration of sensory and motor blockade as well as in their total duration of analgesia.

Conclusions: We conclude that in supraclavicular brachial plexus block addition of dexmedetomidine to ropivacaine shortens the onset of sensory and motor blockade and prolongs the total duration of sensory and motor block as well as total duration of analgesia.
\end{abstract}

Copy Right, IJAR, 2017,. All rights reserved. 


\section{Introduction:-}

Supraclavicular brachial plexus block provide an ideal operative condition with adequate muscle relaxation, stable intraoperative hemodynamics and post-operative analgesia for upper extremity surgeries. It is carried out at the level of distal trunks of brachial plexus. Various local anaesthetic agents have been used for brachial plexus block in upper limb surgeries and for postoperative analgesia. Previously most commonly used local anaesthetic agents were lignocaine and bupivacaine. Lignocaine has faster onset of action but shorter duration of analgesia while bupivacaine is associated with higher incidence of cardiovascular toxicity. Different additives have been used to prolong the block and to decrease the dose as well as side effects of local anesthetic agents. Lots of adjuvants like morphine, ${ }^{[1]}$ pethidine, ${ }^{[2]}$ neostigmine ${ }^{[3]}$ midazolam, ${ }^{[4]}$ dexamethasone and several others have been used in combination with lignocaine and bupivacaine previously, but the results were either inconclusive or associated with side effects. $^{[5-7]}$

A newer long acting local anaesthetic agent ropivacaine hydrochloride, a chemical congener of bupivacaine is being used for providing brachial plexus block. Ropivacaine is a pure S-enantiomer having greater local anaesthetic potency and is less toxic than bupivacaine but more toxic than lidocaine. ${ }^{[8,9]}$ It is less likely to penetrate the large myelinated motor fibers thereby resulting in a relatively reduced motor blockade, thereby having greater degree of motor-sensory differentiation.

Dexmedetomidine hydrochloride, a highly selective alpha2 agonist is 8 times more selective alpha2 adreno-receptor agonist as compare to clonidine. It is found to be safe and effective in various neuraxial and regional anaesthetic techniques. ${ }^{[10,11]}$ It has been shown to have both sedative and analgesic effects. ${ }^{[12,13]}$ This study was planned to evaluate the effect of addition of dexmedetomidine hydrochloride on onset and duration of anaesthesia, analgesia and motor blockade in supraclavicular brachial plexus block using ropivacaine hydrochloride.

\section{Patients and Methods:-}

Ethical committee clearance and informed consent was obtained from all patients before assigning them to study or control group. Sixty patients within age group of 18 to 55 years and ASA class I and II posted for upper limb plastic surgical elective procedures were included in the study. Using computer generated numbers the patients were randomly assigned into study and control groups, with total 30 patients to each group. Study Group RD (n = 30)

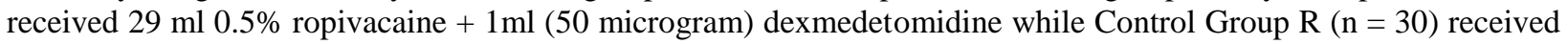
$29 \mathrm{ml} 0.5 \%$ ropivacaine $+1 \mathrm{ml}$ normal saline. Patients excluded from study were those with any bleeding disorders or patients taking anticoagulants, patients having neurological deficits involving brachial plexus, patients allergic to local anesthetics or to dexmedetomidine, patients having active infection at the site of local injection, patients on any sedatives or antipsychotics and those patients which were suffering from any cardiac or pulmonary disease. An intravenous 18 gauge cannula was inserted in hand of non-operative side on arrival of the patient in an operating room and Ringer Lactate infusion was started. The patient's heart rate (HR), systolic blood pressure (SBP), diastolic blood pressure (DBP), mean arterial blood pressure (MAP), electrocardiogram (ECG) and oxygen saturation (SPO2) were continuously monitored. The baseline heart rate and blood pressure were recorded. The supraclavicular brachial plexus block was performed with the help of nerve stimulator technique by the classical approach using a single injection. The electrical stimulation was started with pulse width of $100 \mu$ s and intensity of $2.0 \mathrm{~mA}$. Once the desired response was observed - that is a clear muscle twitch of the fingers - the strength of current was decreased in increments of $0.2 \mathrm{~mA}$ gradually till $0.4 \mathrm{~mA}$. The drug solution was injected if desired response persisted at $0.4 \mathrm{~mA}$. The study drug was injected in $3 \mathrm{ml}$ increments, after a negative aspiration test in-between. During the surgery heart rate, systolic, diastolic and mean arterial blood pressures were noted every 5 minutes (mins) during the initial $15 \mathrm{mins}$, then every 15 minutes throughout the surgery and hourly in post-operative period.

The parameters studied were:-

Onset and duration of Sensory block: Sensory block was assessed by pinprick test using 28-gauge needle at intervals of one minute, after completion of drug infiltration in all three nerve territories of hand until complete sensory blockade was achieved.

Sensory block was assessed by a 3-point scale:

1. normal sensation,

2. Complete loss of pinprick sensation (analgesia),

3. Complete loss of touch sensation (anaesthesia). 
Onset time period of sensory block was defined as the time interval between the end of local anaesthetic administration and achievement of complete sensory block (score 2).

Duration of sensory block was defined as the time interval between the onset of complete sensory block till complete resolution of anaesthesia (score 0 ).

Onset and duration of motor block:-

Modified Bromage Scale (MBS) was used to assess motor blockade: ${ }^{[14,15]}$

1. Normal motor function,

2. Able to move only fingers,

3. Complete motor block with inability to move fingers, wrist and elbows.

Motor block onset time was defined as the time interval between the end of total local anaesthetic infiltration and starting time of complete motor block (MBS score 2).

Duration of motor block was defined as the time interval from the onset of motor blockade till recovery of complete motor function (MBS score 0).

\section{Duration of analgesia or first request for analgesic/ requirements in first 24 hrs:-}

Pain was assessed using a standard 0 to 10 Visual Analogue Scale (VAS) by an independent observer. Time for first request of postoperative analgesic was noted. Intravenous tramadol $100 \mathrm{mg}$ was given as a rescue analgesic if VAS score was 4 or more. Number of requirements of rescue analgesic agent in first post-operative $24 \mathrm{hrs}$ was noted.

Incidence of nausea, vomiting, phrenic nerve palsy, Horner's syndrome, pneumothorax, respiratory depression and other side effects related to local anesthetics was looked for and noted. The above observations were made by the principal investigator who was blinded for the group to which observed patient belonged to.

\section{Management of unsuccessful block:-}

Inadequate sensory or motor blockade even after 30mins following the infiltration was considered as unsuccessful block. In that circumstance, the block was supplemented with general anaesthesia and such patients were excluded from the study.

\section{Statistical Analysis:-}

Descriptive statistical analysis has been carried out in our study. Results are presented as Mean \pm SD. The student " $t$ " test has been used to determine whether there is statistical difference between study and control groups in the parameters measured. In the above tests the "p" value of less than 0.05 was considered as statistical significant. Data analysis was carried out using Statistical Package for Social Science (SPSS version 17) and Microsoft word and Excel have been used to generate tables.

\section{Results:-}

The groups were well matched for age, weight \& male: female ratio. Both groups had male patients predominantly. The statistical difference was insignificant $(\mathrm{p}>0.05)$. (Table 1)

Table 1:-Demographic Profile of two groups.

\begin{tabular}{|c|c|c|c|c|c|}
\hline \multirow{2}{*}{ Parameters } & \multicolumn{2}{|c|}{ Group R } & \multicolumn{2}{c|}{ GROUP RD } & \multirow{2}{*}{ P-VALUE } \\
\cline { 2 - 5 } & Mean & \pm SD & Mean & \pm SD & 0.7003 \\
\hline Age(years) & 34.2 & 11.34 & 35.5 & 14.50 & 0.438 \\
\hline Weight(Kgs) & 60.11 & 6.60 & 58.8 & 6.40 & \\
\hline Sex(M:F) & \multicolumn{2}{|c|}{$22: 7$} & \multicolumn{2}{c|}{$19: 11$} \\
\hline
\end{tabular}

Table 2:-Comparison of observed parameters between two groups

\begin{tabular}{|c|c|c|c|c|c|}
\hline \multirow{2}{*}{ Parameters } & \multicolumn{2}{|c|}{ GROUP R } & \multicolumn{2}{|c|}{ GROUP RD } & \multirow{2}{*}{ P value } \\
\cline { 2 - 5 } & Mean & \pm SD & Mean & \pm SD & $<0.001$ \\
\hline $\begin{array}{c}\text { Onset time of sensory } \\
\text { blockade(min) }\end{array}$ & 5.1 & 0.91 & 3.2 & 0.82 & $<0.001$ \\
\hline Duration of sensory & 455.31 & 19.31 & 693 & 11.01 & \\
\hline
\end{tabular}




\begin{tabular}{|c|c|c|c|c|c|}
\hline blockade(min) & & & & & \\
\hline $\begin{array}{c}\text { Onset time of motor } \\
\text { blockade(min) }\end{array}$ & 11.21 & 1.81 & 6.45 & 0.92 & $<0.001$ \\
\hline Duration of motor blockade(min) & 365 & 18.41 & 656 & 18.26 & $<0.001$ \\
\hline Duration of Analgesia(min) & 481.31 & 16.02 & 718.32 & 11.25 & $<0.001$ \\
\hline
\end{tabular}

Mean onset time of sensory blockade was $5.1 \pm 0.91 \mathrm{~min}$ in group R, and 3.2 $\pm 0.82 \mathrm{~min}$ in group RD. Duration of sensory blockade was $455.31 \pm 19.31 \mathrm{~min}$ in group R and $693 \pm 11.01 \mathrm{~min}$ in group RD. Mean onset time of motor blockade was $11.21 \pm 1.81 \mathrm{~min}$ in group $\mathrm{R} \& 6.45 \pm 0.92 \mathrm{~min}$ in group RD. The duration of motor blockade (mean $\pm \mathrm{SD}$ ) was $365 \pm 18.41 \mathrm{~min}$ in group R \& $656 \pm 18.26 \mathrm{~min}$ in group RD. Duration of analgesia was $481.31 \pm 16.02 \mathrm{~min}$ in Group R and $718.32 \pm 11.25 \mathrm{~min}$ in group RD. There was highly significant difference between control group $\mathrm{R}$ and group RD with respect to onset of sensory and motor blockade $(p<0.001)$. Duration of sensory and motor blockade was significantly prolonged in group RD. Duration of analgesia was also longer in group RD than control group $(\mathrm{p}<0.001)$. (Table 2$)$

Baseline hemodynamic values were comparable in both groups. No significant difference was found between two groups with respect to adverse events.

\section{Discussion:-}

Peripheral nerve blocks produce a long lasting, site specific effective analgesia and anaesthesia. They avoid side effects of general anaesthetic drugs. Supraclavicular block is a common nerve block used for upper limb surgeries. Many long acting local anesthetic drugs have been utilised. Ropivacaine is a long acting amide which has less cardio-toxic potential. Dexmedetomidine an alpha-2 agonist has sedative, analgesic and perioperative sympatholytic and hemodynamic stability properties. It decreases anaesthetic and analgesic requirements. In our study we evaluated the effect of addition of dexmedetomidine $(50 \mathrm{mcg})$ to ropivacaine in supraclavicular block. Results of our study infer that onset of sensory \& motor blockade were rapid with adding dexmedetomidine to ropivacaine. Our observations are in accordance with the findings of Esmaoglu A et al. ${ }^{[16]}$ who evaluated the effect of dexmedetomidine added to levobupivacaine for brachial plexus block and observed that the onset of sensory \& motor blockade was shorter $(9.03 \pm 1.15 \mathrm{~min}, 9.50 \pm 1.04 \mathrm{~min}$ respectively $)$ in dexmedetomidine group than (10.46 \pm 1.30 min, $11.10 \pm 1.24$ min respectively) in control Group. Similar findings were observed by Ammar and Mahmoud. ${ }^{[17]}$ Our findings revealed that duration of sensory \& motor blockade prolonged in group RD as compared to group R. This may be because peripheral alpha2 agonist produces analgesia by reducing the release of norepinephrine leading to alpha2 receptor independent inhibitory effects on nerve fiber action potential. Centrally, alpha2 agonist produces sedation and analgesia by abolition of Substance $\mathrm{P}$ release in nociceptive pathway at the level of dorsal horn and activation of alpha2 receptor in locus ceruleus. ${ }^{[18]}$ Our observations were in accordance with the findings of Swami SS et al. ${ }^{[19]}$ they used alpha2 agonist with local anaesthetic to extend the duration of peripheral nerve blocks. Ammar and Mahmoud ${ }^{[17]}$ observed that adding dexmedetomidine $(0.75 \mathrm{mcg} / \mathrm{kg})$ to bupivacaine $(0.33 \%)$ significantly prolonged the duration of sensory \& motor blockade as compared to bupivacaine alone.

Duration of analgesia as assessed by Visual analog scale (VAS) was prolonged in group RD as compared to control Group. Our observations were in accordance with the findings of Kathuria S et al. ${ }^{[20]}$ Esmaoglu A et al. ${ }^{[16]} \&$ Swami SS et al. ${ }^{[19]}$

\section{Conclusion:-}

An addition of dexmedetomidine $50 \mu \mathrm{g}$ to ropivacaine shortens the onset of sensory and motor blockade, prolongs the duration of sensory and motor blockade \& increases total duration of analgesia. Thus dexmedetomidine is an effective choice as an adjuvant to ropivacaine in supraclavicular brachial plexus block for patients undergoing upper limb plastic surgical or other procedures.

\section{Financial support and Sponsorship:-}

Nil

\section{Conflicts of Interest:-}

There are no conflicts of interest. 


\section{References:-}

1. Bazin Je, Massoni C, Brulle P, Fenies V, Groslier D, Schoeffler P. The Addition Of Opoids To La In Brachial Plexus Blocks The Comparative Study Of Effect Of Morphine, Buprenorphine And Sufentanyl. Anaesthsia 1997; 52:858-862.

2. Sadeghi SA, Soleimani AA, Soleimanifar M. Supplemental Pethidine and Fentanyl to local anesthetics in supraclavicular block. ActaMedicaIranica. 2003; 41(2):134-7.

3. Murphy DB, McCartney CJ, Chan VW. Novel analgesic adjuncts for brachial plexus block: a systematic review. Anesthesia \& Analgesia. 2000 May 1; 90(5):1122-8.

4. Jarbo K, Batra YK, Nidhi M, Panda B. Brachial plexus block with midazolam and bupivacaine improves analgesia. Canadian Journal of Anesthesia. 2005 Oct 1; 52(8):822-6.

5. Wakhlo R, Gupta V, Raina A, Gupta SD, Lahori VU. Supraclavicular plexus block: Effect of adding tramadol or butorphanol as an adjuncts to local anaesthetic on motor and sensory block and duration of post-operative analgesia. Journal of Anaesthesiology Clinical Pharmacology. 2009 Jan 1; 25(1):17.

6. Iohom G, Machmachi A, Diarra DP, Khatouf M, Boileau S, Dap F, Boini S, Mertes PM, Bouaziz H. The effects of clonidine added to mepivacaine for paronychia surgery under axillary brachial plexus block. Anesthesia \& Analgesia. 2005 Apr 1; 100(4):1179-83.

7. Lalla RK, Anant S, Nanda HS. Verapamil as an adjunct to local anaesthetic for brachial plexus blocks. Medical Journal Armed Forces India. 2010 Jan 31; 66(1):22-4.

8. Åkerman B, Hellberg IB, Trossvik C. Primary evaluation of the local anaesthetic properties of the amino amide agent ropivacaine (LEA 103). Actaanaesthesiologicascandinavica. 1988 Oct 1; 32(7):571-8.

9. Reiz S, Häggmark S, Johansson G, Nath S. Cardiotoxicity of ropivacaine-a new amide local anaesthetic agent. ActaAnaesthesiologicaScandinavica. 1989 Feb 1; 33(2):93-8.

10. Kanazi GE, Aouad MT, Jabbour-Khoury SI, Al Jazzar MD, Alameddine MM, Al-Yaman R, Bulbul M, Baraka AS. Effect of low-dose dexmedetomidine or clonidine on the characteristics of bupivacaine spinal block.ActaAnaesthesiologicaScandinavica. 2006 Feb 1; 50(2):222-7.

11. Congedo E, Sgreccia M, De Cosmo G. New drugs for epidural analgesia.Current drug targets. 2009 Aug 1; 10(8):696-706.

12. Kauppila T, Kemppainen P, Tanila H, Pertovaara A. Effect of systemic medetomidine, an alpha 2 adrenoceptor agonist, on experimental pain in humans. Anesthesiology. 1991 Jan; 74(1):3-8

13. Venn RM, Bradshaw CJ, Spencer R, Brealey D, Caudwell E, Naughton C, Vedio A, Singer M, Feneck R, Treacher D, Willatts SM. Preliminary UK experience of dexmedetomidine, a novel agent for postoperative sedation in the intensive care unit.Anaesthesia. 1999 Dec 1; 54(12):1136-42.

14. Peterson Kandall F, Kendall Mccreary E, EdsMuskeln : Function And Tests. New York: Gustav Fischer VerlagStuwartt 1988: 3-13.

15. Crichton N. Visual analogue scale (VAS). J ClinNurs. 2001 Sep 1; 10(5):706-6.

16. Esmaoglu A, Yegenoglu F, Akin A, Turk CY. Dexmedetomidine added to levobupivacaine prolongs axillary brachial plexus block. Anesthesia \& Analgesia. 2010 Dec 1; 111(6):1548-51.

17. Ammar AS, Mahmoud KM. Ultrasound-guided single injection infraclavicular brachial plexus block using bupivacaine alone or combined with dexmedetomidine for pain control in upper limb surgery: A prospective randomized controlled trial. Saudi journal of anaesthesia. 2012 Apr 1; 6(2):109.

18. Guo TZ, Jiang JY, Buttermann AE, Maze M. Dexmedetomidine injection into the locus ceruleus produces antinociception. The Journal of the American Society of Anesthesiologists. 1996 Apr 1; 84(4):873-81.

19. Swami SS, Keniya VM, Ladi SD, Rao R. Comparison of dexmedetomidine and clonidine ( $\alpha 2$ agonist drugs) as an adjuvant to local anaesthesia in supraclavicular brachial plexus block: A randomised double-blind prospective study. Indian journal of anaesthesia. 2012 May 1; 56(3):243.

20. Kathuria S, Gupta S, Dhawan I. Dexmedetomidine as an Adjuvant to Ropivacaine in Supraclavicular Brachial Plexus Block. Saudi Journal of Anaesthesia. 2015 Apr; 9(2):148-154. 